\title{
Fate of heavy metals in sewage and polluted water bodies
}

\author{
Harsha Rao, Lakshminarayana Rao* and H. N. Chanakya \\ Centre for Sustainable Technologies, Indian Institute of Science, Bengaluru 560 012, India
}

There is a major knowledge gap and a multifarious problem involving metal chemistry, physical interactions of metals, microbiology, aerobic and anaerobic processes in understanding the precipitation of heavy metals in sewage and polluted water bodies. This study focuses on determining the most feasible metalsalt that can be formed using standard Gibbs free energy change for each possible reaction of all the heavy metals in wastewater. Solubility limits of all possible metal salts are computed. It is shown that even in the short anaerobic stage, any heavy metal will have the propensity to precipitate as sulphides and form insoluble salts, thus rendering the wastewater free from heavy metals. The measured heavy metal concentration in treated wastewater from Bangalore's $\mathrm{K}-\mathrm{C}$ Valley and Bellandur sewage treatment plants is presented as a validation of the theory.

Keywords: Anaerobic digestion, heavy metals, precipitation, solubility limit, wastewater.

\section{Origin of heavy metals in urban sewage and threat to lakes}

THE ever increasing sewage generation from urbanization and consequent threats to water resources are important concerns to sustainable development. Majority of the world's population now lives in the cities ${ }^{1-6}$. Nearly onethird of the Indian population is urbanized and many states are expected to have more than half of their population in cities by 2021 (ref. 7). Most cities have little wastewater infrastructure ${ }^{8}$. Cities have become large sinks for water and epicentres for wastewater (sewage). Cities usurp water from hundreds of kilometres away while the rainwater collection tanks have become receptacles of sewage. When untreated sewage flows under anaerobic conditions, most of the metals present are precipitated and deposited as a heavy metal (HM)-rich sludge ${ }^{9}$.

Cities in the Deccan Plateau have always aligned their sewerage systems along with the natural contours of land and water basins. These water bodies have become perpetually filled with sewage. For example, Varthur and Bellandur lakes of Bengaluru, Musi in Hyderabad and

\footnotetext{
*For correspondence. (e-mail: narayana@iisc.ac.in)
}

River Cooum in Chennai receive large volumes of urban sewage. As cities are industrialized, storm water, sewage and industrial effluents became mixed and flow as common wastewater. For a significant period, industries in Bengaluru such as battery reconditioning, electroplating and paint shops have released effluents bearing HMs into sewage $^{10}$. It is unclear what happens to these HMs in sewage streams. The present study answers this question using both thermodynamic potential and solubility limitations.

By definition, metallic elements and metalloids having atomic density $>5 \mathrm{~g} / \mathrm{cm}^{3}$ are termed as 'heavy metals ${ }^{11,12}$; for example, As $\left(5.75 \mathrm{~g} / \mathrm{cm}^{3}\right), \mathrm{Zn}\left(7.14 \mathrm{~g} / \mathrm{cm}^{3}\right)$, $\mathrm{Cr}\left(7.15 \mathrm{~g} / \mathrm{cm}^{3}\right), \mathrm{Mn}\left(7.30 \mathrm{~g} / \mathrm{cm}^{3}\right), \mathrm{Fe}\left(7.87 \mathrm{~g} / \mathrm{cm}^{3}\right), \mathrm{Cd}$ $\left(8.69 \mathrm{~g} / \mathrm{cm}^{3}\right), \quad$ Co $\left(8.86 \mathrm{~g} / \mathrm{cm}^{3}\right), \quad \mathrm{Ni}\left(8.90 \mathrm{~g} / \mathrm{cm}^{3}\right), \quad \mathrm{Cu}$ $\left(8.96 \mathrm{~g} / \mathrm{cm}^{3}\right), \quad$ Mo $\left(10.2 \mathrm{~g} / \mathrm{cm}^{3}\right), \quad \mathrm{Ag}\left(10.5 \mathrm{~g} / \mathrm{cm}^{3}\right), \quad \mathrm{Pb}$ $\left(11.30 \mathrm{~g} / \mathrm{cm}^{3}\right)$ and $\mathrm{Hg}\left(13.53 \mathrm{~g} / \mathrm{cm}^{3}\right)$. Selenium having an atomic density of $4.8 \mathrm{~g} / \mathrm{cm}^{3}$ is also included in this list given its toxic nature. All these HMs, except silver, are toxic. Although the dominant material of sewage is consumed food, several other household chemicals also enter it. Food contains only insignificant levels of HMs and over $99 \%$ of the digestible organic food matter is absorbed by humans. Rejects are further digested as sewage decomposes rapidly, anaerobically or aerobically, leaving behind these unused HMs. Sewage, especially as settled sludge, is known to accumulate these HMs and is often considered as an environmental threat ${ }^{12,13}$.

The Environmental Protection rules of 1986 have specified the discharge standards for $10 \mathrm{HMs}$, namely As, $\mathrm{Hg}, \mathrm{Pb}, \mathrm{Cd}, \mathrm{Cr}^{+6}, \mathrm{Cr}, \mathrm{Cu}, \mathrm{Zn}, \mathrm{Se}$ and $\mathrm{Ni}^{14}$. A few recent reports claim that these $\mathrm{HMs}$ are present in amounts higher than the permissible limits in urban sewage ${ }^{15-21}$. Bioaccumulation of HMs in the riverine/lacustrine systems and the risk of reusing sewage water on health, agriculture and environment have been reported. For example, according to a study on crops and soils receiving sewage from Bellandur, Byramangala, Nagavara and Varthur tanks in Bengaluru, the average HM concentration of water from these water bodies ranged from 0.014 to $0.039 \mathrm{mg} / \mathrm{l}$ for $\mathrm{Cd}, 0.039$ to $0.075 \mathrm{mg} / \mathrm{l}$ for $\mathrm{Pb}, 0.120$ to $0.311 \mathrm{mg} / \mathrm{l}$ for $\mathrm{Cr}$ and 0.027 to $0.042 \mathrm{mg} / \mathrm{l}$ for $\mathrm{Ni}^{22}$. The concentration of $\mathrm{Pb}$ and $\mathrm{Ni}$ was within the safe limits of $0.5 \mathrm{mg} / \mathrm{l}$ and $0.2 \mathrm{mg} / \mathrm{l}$ respectively, according to the guidelines for irrigation water ${ }^{22}$. Nevertheless, it is not clear how these levels, well above typical solubility 
levels of their respective sulphides, have been reported from sewage under chronic anaerobic conditions.

Several studies have indicated that under anaerobic conditions, in the presence of hydrogen sulphide $\left(\mathrm{H}_{2} \mathrm{~S}\right)$, HMs present in the sewage tend to rapidly precipitate or bind to the sludge, forming metal sulphides which precipitate out of the water given their low water solubility ${ }^{23-25}$. Being highly insoluble, they need to be resolubilized into forms that plants can take up and such a process is unlikely to take place with sewage under normal conditions.

This study evaluates the fate of HMs in urban sewage. A thermodynamic study based on standard Gibbs free energy change $\left(\Delta G^{0}\right)$ was conducted to determine which metal-salts will be formed spontaneously under anaerobic conditions. The $\Delta G^{0}$ values were calculated for each possible reaction of all the HMs with other anions and neutral species. The most spontaneous reactions based on the lowest $\Delta G^{0}$ values were determined to arrive at the most feasible product salt formed. Based on the solubility limits of the salts formed, this study shows that HMs present in the sewage will turn almost immediately into insoluble sulphides which will precipitate out of the water, thus rendering the wastewater free from HMs.

\section{Water chemistry of heavy metals in urban sewage}

Unlike the tanks filled by run-off and drying off during summer, sewage-fed water bodies remain continuously filled for decades and show macrophyte infestation ${ }^{26}$. Within a few minutes of discharge of sewage, it gets mixed with a larger sewage flow and rapid digestion of the organics begin. This absorbs all dissolved oxygen and the sewage first becomes anoxic and almost immediately anaerobic. Under anaerobic conditions hydrogen $\left(\mathrm{H}_{2}\right)$ is generated and sulphate-reducing bacteria converts the sulphur in organic matter and products of fermentations to $\mathrm{H}_{2} \mathrm{~S}$ and $\mathrm{HCO}_{3}^{-}$(eq. (1)) ${ }^{27}$. Nitrates and sulphates are used in place of oxygen, releasing $\mathrm{H}_{2}, \mathrm{CO}_{2}, \mathrm{NH}_{3}$ and more $\mathrm{H}_{2} \mathrm{~S}$. The redox potential measured against a standard hydrogen electrode falls below $-200 \mathrm{mV} . \mathrm{CO}_{2}$ is reduced to $\mathrm{CH}_{4}$ using $\mathrm{H}_{2}$ by methanogenic bacteria. The redox potential drops up to $-400 \mathrm{mV}$, a stage at which few metals can remain in soluble form. The $\mathrm{H}_{2} \mathrm{~S}$ produced $(\sim-50 \mathrm{mV})$ reacts with the metals present to form insoluble metal sulphides that subsequently precipitate (eq. (2) $)^{28}$. This precipitation can be correlated with the Kipp's apparatus. This is used to generate $\mathrm{H}_{2} \mathrm{~S}$, which when bubbled through metallic salt solutions of either $\mathrm{Pb}, \mathrm{Ag}$ or $\mathrm{Cu}$ forms a black precipitate almost immediately, even as $\mathrm{H}_{2} \mathrm{~S}$, was brought near the salt solution ${ }^{29} . \mathrm{H}_{2} \mathrm{~S}$ readily reacts with metal ions to give corresponding metal sulphides.

$$
2 \mathrm{CH}_{2} \mathrm{O}+\mathrm{SO}_{4}^{2-} \rightarrow \mathrm{H}_{2} \mathrm{~S}+2 \mathrm{HCO}_{3}^{-}
$$

(in the presence of anaerobic bacteria), where $-\mathrm{CH}_{2} \mathrm{O}$ represents organic matter.

$$
\mathrm{M}^{2+}+\mathrm{H}_{2} \mathrm{~S} \leftrightarrow \mathrm{MS}(\mathrm{s}) \downarrow+2 \mathrm{H}^{+},
$$

where $\mathrm{M}$ includes metals such as $\mathrm{Fe}, \mathrm{Cu}, \mathrm{Zn}, \mathrm{Ni}, \mathrm{Cd}$, etc.

The metal sulphides formed because of anaerobic conditions have very low solubility in water over a wide $\mathrm{pH}$ range $^{30}$. These HM-sulphide salts bind to the sludge which gradually settles as sludge or silt at the lake bottom.

\section{Standard Gibbs free energy change for heavy metal salts in urban sewage}

Table 1 shows the standard Gibbs free energy $\left(\Delta G^{0}\right)$ of all possible reactions for $13 \mathrm{HMs}^{31,32}$. As shown in table, for each metal, $\Delta G^{0}$ for the formation of metal sulphide is the lowest, indicating that metal sulphide formation is more spontaneous/favourable compared to all other metallic salt formations, namely metal hydroxides, chlorides, fluorides, phosphates, chromates, bromates, bromides, carbonates, metal iodates, metal iodides, nitrates and metal sulphates. This result matches with the earlier studies confirming formation of metal sulphides in sewage $^{23-25}$ and as explained by eq. $(2)^{28}$. Also, this result agrees with earlier studies which have reported that sulphide precipitates are thermodynamically the most copious product in the inorganic fraction under anaerobic conditions and HMs will precipitate as sulphides to form insoluble salts ${ }^{23}$. These data strongly indicate that propensity of metal-sulphide formation in wastewater is the highest and will occur rapidly, if not instantly.

\section{Solubility of heavy metal salts in urban sewage}

Solubility limits of salts in a liquid can be determined by calculating the solubility product $\left(K_{\mathrm{sp}}\right)$ at a given $\mathrm{pH}$ and temperature $^{33}$. Table 1 lists the $K_{\mathrm{sp}}$ and solubility of various metal salts at $298.15 \mathrm{~K}$. As shown in the table, the solubility of sulphides is the least at room temperature (e.g. for $\mathrm{HgS}$ solubility at $298.15 \mathrm{~K}$ is $1.47 \times 10^{-11} \mathrm{mg} / \mathrm{l}$ ), indicating that the metal sulphides are least soluble in water. Metal ligands are formed based on Lewis's acidbase interactions. Hard ions (such as $\mathrm{Al}^{3+}, \mathrm{Ba}^{2+}, \mathrm{Be}^{2+}$, $\mathrm{Co}^{3+}, \mathrm{Cr}^{3+}$ ) have highest affinity towards ions of hard bases (such as $\mathrm{OH}^{-}, \mathrm{SO}_{4}^{2-}, \mathrm{CO}_{3}^{2-}, \mathrm{HCO}_{3}^{-}$) to form ionic complexes and are less toxic in nature. Soft acid ions (such as $\mathrm{Ag}^{+}, \mathrm{Cd}^{2+}, \mathrm{Cu}^{+}, \mathrm{Hg}^{2+}$ ) have highest affinity towards ions of soft base ( $\mathrm{such}$ as $\mathrm{HS}^{-}, \mathrm{S}^{2-}, \mathrm{CN}^{-}$) to form covalent complexes and are toxic in nature. The tendency of metals to form solid phases, such as sulphides, is related to their hard and soft (Lewis) acids and base qualities $^{34}$. Each metal has a specific affinity with each anionic system and the order of precipitation is dependent 


\section{RESEARCH ARTICLES}

Table 1. Standard Gibbs free energy change of the reaction, selected solubility product constants and solubility of heavy metals at $298.15 \mathrm{~K}, 1$ bar (at zero ionic strength) ${ }^{31,32}$

\begin{tabular}{|c|c|c|c|}
\hline Reaction & $\Delta G_{298.15 \mathrm{~K}, 1 \text { bar }}^{0}(\mathrm{~kJ} / \mathrm{mol})$ & $K_{\text {sp }}$ at $298.15 \mathrm{~K}$ & Solubility $(\mathrm{mg} / \mathrm{l})$ at $298.15 \mathrm{~K}$ \\
\hline \multicolumn{4}{|l|}{ Arsenic (As) } \\
\hline $2 \mathrm{As}^{3+}+3 \mathrm{~S}^{2-} \rightarrow \mathrm{As}_{2} \mathrm{~S}_{3}$ & -422.3 & $2.1 \times 10^{-22}$ & $5.17 \times 10^{-5}$ at $291.15 \mathrm{~K}$ \\
\hline $\mathrm{As}^{3+}+3 \mathrm{~F}^{-} \rightarrow \mathrm{AsF}_{3}$ & 64.1 & - & - \\
\hline $\mathrm{As}^{3+}+3 \mathrm{I}^{-} \rightarrow \mathrm{AsI}_{3}$ & 97.3 & - & - \\
\hline $\mathrm{As}^{3+}+3 \mathrm{Cl}^{-} \rightarrow \mathrm{AsCl}_{3}$ & 136.1 & - & - \\
\hline \multicolumn{4}{|l|}{ Zinc $(\mathrm{Zn})$} \\
\hline $\mathrm{Zn}^{2+}+\mathrm{S}^{2-} \rightarrow \mathrm{ZnS}$ & -140 & $1.2 \times 10^{-23}$ at $291.15 \mathrm{~K}$ & $3.38 \times 10^{-7}$ at $291.15 \mathrm{~K}$ \\
\hline $\mathrm{Zn}^{2+}+2 \mathrm{OH}^{-} \rightarrow \mathrm{Zn}(\mathrm{OH})_{2}$ & -92 & $3 \times 10^{-17}$ & 0.195 \\
\hline $\mathrm{Zn}^{2+}+\mathrm{CO}_{3}^{2-} \rightarrow \mathrm{ZnCO}_{3}$ & -56.6 & $1.46 \times 10^{-10}$ & 1.515 \\
\hline $\mathrm{Zn}^{2+}+2 \mathrm{~F}^{-} \rightarrow \mathrm{ZnF}_{2}$ & -8.6 & $3.04 \times 10^{-2}$ & $2.03 \times 10^{4}$ \\
\hline $\mathrm{Zn}^{2+}+2 \mathrm{NO}_{3}^{-} \rightarrow \mathrm{Zn}\left(\mathrm{NO}_{3}\right)_{2}$ & 0.1 & - & $5.46 \times 10^{5}$ \\
\hline $\mathrm{Zn}^{2+}+\mathrm{SO}_{4}^{2-} \rightarrow \mathrm{ZnSO}_{4}$ & 20.1 & - & $3.66 \times 10^{5}$ \\
\hline $\mathrm{Zn}^{2+}+2 \mathrm{Cl}^{-} \rightarrow \mathrm{ZnCl}_{2}$ & 40.1 & - & $8.03 \times 10^{5}$ \\
\hline $\mathrm{Zn}^{2+}+2 \mathrm{I}^{-} \rightarrow \mathrm{ZnI}_{2}$ & 41.3 & - & $8.14 \times 10^{5}$ \\
\hline $\mathrm{Zn}^{2+}+2 \mathrm{Br}^{-} \rightarrow \mathrm{ZnBr}_{2}$ & 43 & - & $8.3 \times 10^{5}$ \\
\hline \multicolumn{4}{|l|}{ Chromium (Cr) } \\
\hline $\mathrm{Cr}^{2+}+\mathrm{S}^{2-} \rightarrow \mathrm{CrS}$ & -305.8 & Insoluble & Insoluble-- \\
\hline $\mathrm{Cr}^{3+}+3 \mathrm{~F}^{-} \rightarrow \mathrm{CrF}_{3}$ & -57.1 & $6.6 \times 10^{-11}$ & $1.36 \times 10^{2}$ \\
\hline $\mathrm{Cr}^{3+}+3 \mathrm{Cl}^{-} \rightarrow \mathrm{CrCl}_{3}$ & 102 & - & $5.9 \times 10^{5}$ at $293.15 \mathrm{~K}\left(\right.$ for $\left.\mathrm{CrCl}_{3} \cdot 6 \mathrm{H}_{2} \mathrm{O}\right)$ \\
\hline
\end{tabular}

$\begin{array}{lr}\text { Manganese }(\mathrm{Mn}) & \\ \mathrm{Mn}^{3+}+\mathrm{S}^{2-} \rightarrow \mathrm{MnS} & -76.1 \\ \mathrm{Mn}^{2+}+2 \mathrm{Cl}^{-} \rightarrow \mathrm{MnCl}_{2} & -0.3 \\ \left.\mathrm{Mn}^{2+}+2 \mathrm{NO}_{3}^{-} \rightarrow \mathrm{Mn}^{2} \mathrm{NO}_{3}\right)_{2} & -0.3 \\ \mathrm{Mn}^{2+}+\mathrm{SO}_{4}^{2-} \rightarrow \mathrm{MnSO}_{4} & -0.2 \\ \mathrm{Mn}^{2+}+2 \mathrm{Br}^{-} \rightarrow \mathrm{MnBr}_{2} & 26.9 \\ \mathrm{Mn}^{2+}+2 \mathrm{~F}^{-} \rightarrow \mathrm{MnF}_{2} & 36.7\end{array}$

Iron $(\mathrm{Fe})$

$\mathrm{Fe}^{2+}+\mathrm{S}^{2-} \rightarrow \mathrm{FeS}$

$\mathrm{Fe}^{2+}+\mathrm{SO}_{4}^{2-} \rightarrow \mathrm{FeSO}_{4}$

$\mathrm{Fe}^{3+}+3 \mathrm{NO}_{3}^{-} \rightarrow \mathrm{Fe}\left(\mathrm{NO}_{3}\right)_{3}$

Cadmium (Cd)

$\mathrm{Cd}^{2+}+\mathrm{S}^{2-} \rightarrow \mathrm{CdS}$

$\mathrm{Cd}^{2+}+2 \mathrm{OH}^{-} \rightarrow \mathrm{Cd}(\mathrm{OH})_{2}$

$\mathrm{Cd}^{2+}+2 \mathrm{I}^{-} \rightarrow \mathrm{CdI}_{2}$

$\mathrm{Cd}^{2+}+2 \mathrm{~F}^{-} \rightarrow \mathrm{CdF}_{2}$

$\mathrm{Cd}^{2+}+2 \mathrm{Br}^{-} \rightarrow \mathrm{CdBr}_{2}$

$\mathrm{Cd}^{2+}+2 \mathrm{Cl}^{-} \rightarrow \mathrm{CdCl}_{2}$

$\mathrm{Cd}^{2+}+\mathrm{SO}_{4}^{2-} \rightarrow \mathrm{CdSO}_{4}$

$\mathrm{Cd}^{2+}+2 \mathrm{NO}_{3}^{-} \rightarrow \mathrm{Cd}\left(\mathrm{NO}_{3}\right)_{2}$

Cobalt (Co)

$\mathrm{Co}^{2+}+\mathrm{S}^{2-} \rightarrow \mathrm{CoS}$

$\mathrm{Co}^{2+}+2 \mathrm{OH}^{-} \rightarrow \mathrm{Co}(\mathrm{OH})_{2}$

$\mathrm{Co}^{2+}+2 \mathrm{~F}^{-} \rightarrow \mathrm{CoF}_{2}$

$\mathrm{Co}^{2+}+\mathrm{SO}_{4}^{2-} \rightarrow \mathrm{CoSO}_{4}$

$\mathrm{Co}^{2+}+2 \mathrm{I}^{-} \rightarrow \mathrm{CoI}_{2}$

$\mathrm{Co}^{2+}+2 \mathrm{NO}_{3}^{-} \rightarrow \mathrm{Co}\left(\mathrm{NO}_{3}\right)_{2}$

$\mathrm{Co}^{2+}+2 \mathrm{Cl}^{-} \rightarrow \mathrm{CoCl}_{2}$

Nickel (Ni)

$\begin{array}{lr}\mathrm{Ni}^{2+}+\mathrm{S}^{2-} \rightarrow \mathrm{NiS} & -119.7 \\ \mathrm{Ni}^{2+}+2 \mathrm{OH}^{-} \rightarrow \mathrm{Ni}(\mathrm{OH})_{2} & -87.2 \\ \mathrm{Ni}^{2+}+2 \mathrm{~F}^{-} \rightarrow \mathrm{NiF}_{2} & -0.9 \\ \mathrm{Ni}^{2+}+2 \mathrm{NO}_{3}^{-} \rightarrow \mathrm{Ni}\left(\mathrm{NO}_{3}\right)_{2} & -0.3 \\ \mathrm{Ni}^{2+}+\mathrm{SO}_{4}^{2-} \rightarrow \mathrm{NiSO}_{4} & -0.2 \\ \mathrm{Ni}^{2+}+2 \mathrm{I}^{-} \rightarrow \mathrm{NiI}_{2} & -0.2 \\ \mathrm{Ni}^{2+}+2 \mathrm{Cl}^{-} \rightarrow \mathrm{NiCl}_{2} & 49\end{array}$

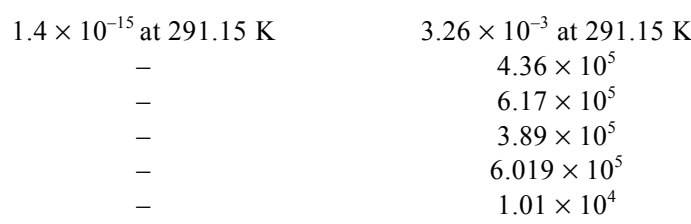


Table 1. (Contd)

\begin{tabular}{|c|c|c|c|}
\hline Reaction & $\Delta G_{298.15 \mathrm{~K}, 1 \text { bar }}^{0}(\mathrm{~kJ} / \mathrm{mol})$ & $K_{\text {sp }}$ at $298.15 \mathrm{~K}$ & Solubility $(\mathrm{mg} / \mathrm{l})$ at $298.15 \mathrm{~K}$ \\
\hline \multicolumn{4}{|l|}{ Copper $(\mathrm{Cu})$} \\
\hline $\mathrm{Cu}^{2+}+\mathrm{S}^{2-} \rightarrow \mathrm{CuS}$ & -204.9 & $8.5 \times 10^{-45}$ at $291.15 \mathrm{~K}$ & $8.81 \times 10^{-18}$ at $291.15 \mathrm{~K}$ \\
\hline $\mathrm{Cu}^{+}+\mathrm{I}^{-} \rightarrow \mathrm{CuI}$ & -67.9 & $1.27 \times 10^{-12}$ & 0.215 \\
\hline $\mathrm{Cu}^{+}+\mathrm{Br}^{-} \rightarrow \mathrm{CuBr}$ & -46.8 & $6.27 \times 10^{-9}$ & $1.136 \times 10^{1}$ \\
\hline $\mathrm{Cu}^{+}+\mathrm{Cl}^{-} \rightarrow \mathrm{CuCl}$ & -38.7 & $1.72 \times 10^{-7}$ & $4.105 \times 10^{1}$ \\
\hline $\mathrm{Cu}^{2+}+2 \mathrm{NO}_{3}^{-} \rightarrow \mathrm{Cu}\left(\mathrm{NO}_{3}\right)_{2}$ & 0.1 & - & $5.92 \times 10^{5}$ \\
\hline $\mathrm{Cu}^{2+}+\mathrm{SO}_{4}^{2-} \rightarrow \mathrm{CuSO}_{4}$ & 12.8 & - & $1.8 \times 10^{5}$ \\
\hline \multicolumn{4}{|l|}{ Molybdenum (Mo) } \\
\hline $\mathrm{Mo}^{4+}+\mathrm{S}^{2-} \rightarrow \mathrm{MoS}_{2}$ & -388.95 & $2.2 \times 10^{-56}$ & $1.9 \times 10^{-23}$ \\
\hline \multicolumn{4}{|l|}{ Silver (Ag) } \\
\hline $2 \mathrm{Ag}^{+}+\mathrm{S}^{2-} \rightarrow \mathrm{Ag}_{2} \mathrm{~S}$ & -280.7 & $6 \times 10^{-30}$ & $2.84 \times 10^{-5}$ \\
\hline $\mathrm{Ag}^{+}+\mathrm{I}^{-} \rightarrow \mathrm{AgI}$ & -91.7 & $8.52 \times 10^{-17}$ & 0.002 \\
\hline $\mathrm{Ag}^{+}+\mathrm{Br}^{-} \rightarrow \mathrm{AgBr}$ & -70 & $5.35 \times 10^{-13}$ & 0.137 \\
\hline $2 \mathrm{Ag}^{+}+\mathrm{CrO}_{4}^{2-} \rightarrow \mathrm{Ag}_{2} \mathrm{CrO}_{4}$ & -68.2 & $1.12 \times 10^{-12}$ & $2.17 \times 10^{1}$ \\
\hline $2 \mathrm{Ag}^{+}+\mathrm{CO}_{3}^{2-} \rightarrow \mathrm{Ag}_{2} \mathrm{CO}_{3}$ & -63.2 & $8.46 \times 10^{-12}$ & $3.539 \times 10^{1}$ \\
\hline $\mathrm{Ag}^{+}+\mathrm{Cl}^{-} \rightarrow \mathrm{AgCl}$ & -55.7 & $1.77 \times 10^{-10}$ & 1.907 \\
\hline $\mathrm{Ag}^{+}+\mathrm{BrO}_{3}^{-} \rightarrow \mathrm{AgBrO}_{3}$ & -24.4 & $5.38 \times 10^{-5}$ & $1.729 \times 10^{3}$ \\
\hline $\mathrm{Ag}^{+}+\mathrm{NO}_{3}^{-} \rightarrow \mathrm{AgNO}_{3}$ & 0.8 & - & $7.01 \times 10^{5}$ \\
\hline \multicolumn{4}{|l|}{ Lead $(\mathrm{Pb})$} \\
\hline $\mathrm{Pb}^{2+}+\mathrm{S}^{2-} \rightarrow \mathrm{PbS}$ & -160.1 & $3.4 \times 10^{-28}$ at $291.15 \mathrm{~K}$ & $4.41 \times 10^{-9}$ at $291.15 \mathrm{~K}$ \\
\hline $\mathrm{Pb}^{2+}+\mathrm{CO}_{3}^{2-} \rightarrow \mathrm{PbCO}_{3}$ & -73.3 & $7.40 \times 10^{-14}$ & 0.073 \\
\hline $\mathrm{Pb}^{2+}+2 \mathrm{I}^{-} \rightarrow \mathrm{PbI}_{2}$ & -46 & $9.8 \times 10^{-9}$ & $6.215 \times 10^{2}$ \\
\hline $\mathrm{Pb}^{2+}+\mathrm{SO}_{4}^{2-} \rightarrow \mathrm{PbSO}_{4}$ & -44.1 & $2.53 \times 10^{-8}$ & $4.824 \times 10^{2}$ \\
\hline $\mathrm{Pb}^{2+}+2 \mathrm{~F}^{-} \rightarrow \mathrm{PbF}_{2}$ & -35.1 & $3.3 \times 10^{-8}$ & $4.95 \times 10^{2}$ \\
\hline $\mathrm{Pb}^{2+}+2 \mathrm{Br}^{-} \rightarrow \mathrm{PbBr}_{2}$ & -29.5 & $6.6 \times 10^{-6}$ & $4.336 \times 10^{3}$ \\
\hline $\mathrm{Pb}^{2+}+2 \mathrm{Cl}^{-} \rightarrow \mathrm{PbCl}_{2}$ & -27.3 & $1.7 \times 10^{-5}$ & $4.504 \times 10^{3}$ \\
\hline $\mathrm{Pb}^{2+}+2 \mathrm{NO}_{3}^{-} \rightarrow \mathrm{Pb}\left(\mathrm{NO}_{3}\right)_{2}$ & 0.1 & - & $3.738 \times 10^{5}$ \\
\hline \multicolumn{4}{|l|}{ Mercury (Hg) } \\
\hline $\mathrm{Hg}^{2+}+\mathrm{S}^{2-} \rightarrow \mathrm{HgS}$ (red) & -300.8 & $4 \times 10^{-33}$ & $1.47 \times 10^{-11}$ \\
\hline $\mathrm{Hg}^{2+}+2 \mathrm{I}^{-} \rightarrow \mathrm{HgI}_{2}$ & -162.9 & $2.9 \times 10^{-29}$ & $8.79 \times 10^{-5}$ \\
\hline $\mathrm{Hg}_{2}^{2+}+2 \mathrm{Br}^{-} \rightarrow \mathrm{Hg}_{2} \mathrm{Br}_{2}$ & -126.6 & $6.40 \times 10^{-23}$ & 0.014 \\
\hline $\mathrm{Hg}^{2+}+2 \mathrm{Br}^{-} \rightarrow \mathrm{HgBr}_{2}$ & -109.5 & - & $6.1 \times 10^{3}$ \\
\hline $\mathrm{Hg}_{2}^{2+}+2 \mathrm{Cl}^{-} \rightarrow \mathrm{Hg}_{2} \mathrm{Cl}_{2}$ & -101.8 & $1.43 \times 10^{-18}$ & 0.335 \\
\hline $\mathrm{Hg}_{2}^{2+}+\mathrm{CO}_{3}^{2-} \rightarrow \mathrm{Hg}_{2} \mathrm{CO}_{3}$ & -93.8 & $3.6 \times 10^{-17}$ & 0.003 \\
\hline $\mathrm{Hg}_{2}^{2+}+\mathrm{SO}_{4}^{2-} \rightarrow \mathrm{Hg}_{2} \mathrm{SO}_{4}$ & -34.8 & $6.5 \times 10^{-7}$ & $2.71 \times 10^{3}$ \\
\hline
\end{tabular}

on the different $K_{\mathrm{sp}}$ values. Lower $K_{\mathrm{sp}}$ indicates lower solubility of the salt. In addition, metal sulphides are amphoteric and only slightly soluble in water ${ }^{35}$. The solubility data in Table 1 suggest that sulphide salts are water-insoluble, and form most stable precipitates under anaerobic conditions ${ }^{34}$.

Another aspect that plays an important role in HM chemistry is pH. Figures 1 and 2 show the solubility of various metal salts in water at different $\mathrm{pH}$ values ${ }^{37}$. As shown in figures for all HMs, their solubility decreases with $\mathrm{pH}$. Under anaerobic conditions, the following processes are known to increase the $\mathrm{pH}$ of wastewater above 8 , from its initial value of $6.8-8.3$, i.e. consumption of volatile fatty acids by methanogens and reduction of sulphate/sulphite to sulphides by sulphate reducing bacteria $^{36}$. Under this $\mathrm{pH}$ condition, the metal sulphides of $\mathrm{Zn}, \mathrm{Cu}, \mathrm{Ni}, \mathrm{Cd}, \mathrm{Fe}, \mathrm{Mn}, \mathrm{Hg}$ and $\mathrm{Ag}$ are less soluble and more likely to form insoluble precipitates ${ }^{26}$.

Under anaerobic conditions, the HMs are known to speciate and shift towards the solid phase, leading to lower concentrations in the liquid phase. The percentage of metals in the liquid phase represents only $0.5-4$ of their total concentrations ${ }^{25}$, whereas the remaining 99.5 96 shifts towards solid precipitate.

These data show that HMs that enter the wastewater systems which become anaerobic during their transport along waste streams, tend to form metal sulphides which rapidly precipitate out due to their low solubility.

\section{Water quality and heavy metal concentration in urban sewage treatment plants}

To validate the above theory, the treated wastewater from $\mathrm{K}-\mathrm{C}$ Valley and Bellandur sewage treatment plant (STPs) were analysed, which have anaerobic digestion as part of their treatment process. Table 2 lists the discharge water quality from these STPs and compares it with the CPCB inland surface water discharge standards. The concentration of metals was determined by inductively coupled 
Table 2. Water quality of sewage treatment plant as on 10 January 2019

\begin{tabular}{|c|c|c|c|}
\hline Parameter & $\begin{array}{l}\text { CPCB: inland surface water } \\
\text { standards }\end{array}$ & K-C Valley STP & Bellandur STP \\
\hline Temperature & $\begin{array}{l}\text { Shall not exceed } 5^{\circ} \mathrm{C} \text { above the } \\
\text { receiving water temperature }\end{array}$ & 24.6 & 24.9 \\
\hline $\mathrm{pH}$ & $5.5-9.0$ & 7.7 & 7.8 \\
\hline Iron (as Fe; mg/l) & 3.0 & 0.363 & 0.321 \\
\hline Manganese (as Mn; mg/l) & 2.0 & 0.024 & 0.006 \\
\hline Zinc (as Zn; mg/l) & 5.0 & BDL & 0.028 \\
\hline Cadmium (as Cd; mg/l) & 2.0 & 0.000057 & BDL \\
\hline Lead (as $\mathrm{Pb} ; \mathrm{mg} / \mathrm{l})$ & 0.1 & BDL & BDL \\
\hline Total arsenic (as As; mg/l) & 0.2 & 0.001 & 0.001 \\
\hline Hexavalent chromium (as $\mathrm{Cr}+6 ; \mathrm{mg} / \mathrm{l})$ & 0.1 & $<0.1$ & $<0.1$ \\
\hline Total chromium (as $\mathrm{Cr} ; \mathrm{mg} / \mathrm{l}$ ) & 2.0 & 0.006 & 0.004 \\
\hline Nickel (as Ni; mg/l) & 3.0 & 0.028 & 0.024 \\
\hline Copper (as $\mathrm{Cu} ; \mathrm{mg} / \mathrm{l}$ ) & 3.0 & 0.001 & 0.000064 \\
\hline Aluminium (as Al; mg/l) & - & 0.109 & 0.02 \\
\hline Barium (as $\mathrm{Ba} ; \mathrm{mg} / \mathrm{l}$ ) & - & 0.045 & 0.01 \\
\hline Boron (as B; mg/l) & - & 0.021 & 0.037 \\
\hline Calcium (as $\mathrm{Ca} ; \mathrm{mg} / \mathrm{l}$ ) & - & 57.8 & 58.45 \\
\hline Magnesium (as Mg; mg/l) & - & 17.16 & 3.35 \\
\hline Selenium (as Se; mg/l) & 0.05 & 0.000698 & 0.008 \\
\hline Silver (as Ag; mg/l) & - & 0.000429 & 0.000395 \\
\hline Mercury (as $\mathrm{Hg} ; \mathrm{mg} / \mathrm{l})$ & 0.01 & 0.00096 & 0.003 \\
\hline Molybdenum (as Mo; mg/l) & - & 0.001 & 0.003 \\
\hline
\end{tabular}

BDL, Below detection limit of $1 \times 10^{-12} \mathrm{mg} / \mathrm{l}$.

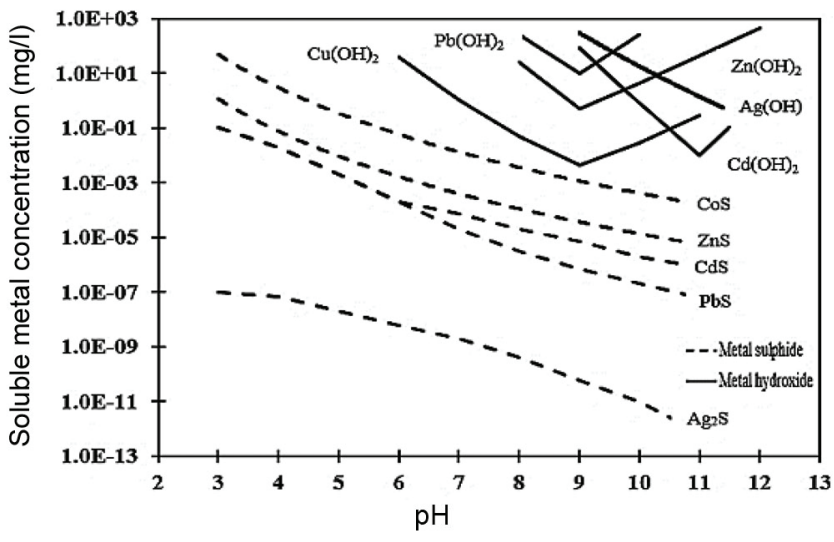

Figure 1. Solubilities of metal hydroxides and sulphides as a function of $\mathrm{pH}^{37}$.

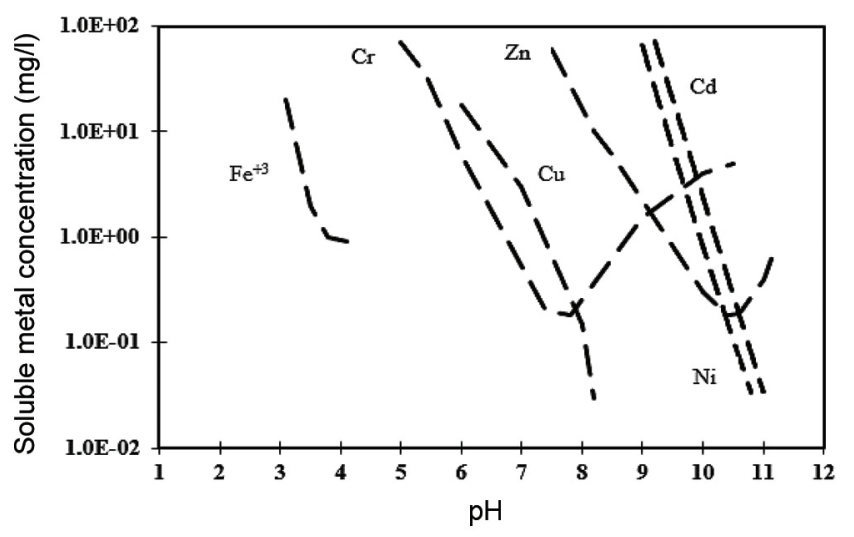

Figure 2. Metal solubilities as a function of $\mathrm{pH}^{37}$. plasma-mass spectrometry (ICP-MS) after filtering the samples using $0.45 \mu \mathrm{m}$ membrane filter and acidifying them in $2 \%$ nitric acid matrix, according to the $\mathrm{APHA}^{38}$. The results indicate that HMs in the secondary treated water that has undergone anaerobic treatment are well below the discharge limits. Table 2 shows that the treated wastewater does not contain any harmful HMs above the prescribed limits, which provides evidence for the above theory of HM-sulphide formation and solubility in sewage systems.

\section{Conclusion}

The relative content of HMs tends to accumulate in urban sewage when organic matter content is sequentially digested in the food chain and often, storm water, sewage and industrial effluents become mixed. Occasionally, small amounts of industrial effluents entering fugitively into sewage-dominant wastewaters pose a serious challenge to the reuse of treated wastewater. The sewage systems under tropical climatic conditions undergo rapid anaerobic digestion leading to precipitation of HMs as metal sulphides. Metal sulphide precipitates are thermodynamically the most copious product in the inorganic fraction of wastewater under anaerobic conditions. It is therefore an important condition that sewage flow is maintained under typical anaerobic conditions, atleast for a few hours, to ensure that HMs if any, are allowed to form insoluble precipitates thus rendering the wastewater free from HMs. This process makes the sewage more 
appropriate for further treatment before it is released back to the environment.

1. Gross, M., The urbanisation of our species. Curr. Biol., 2016, 26 R1205-R1225.

2. Kim, Y. H. and Baik, J. J., Spatial and temporal structure of the urban heat island in Seoul. J. Appl. Meteorol. Climatol., 2005, 44, $591-605$.

3. Ganesh, S. P. S. et al., Decentralized treatment and recycling of greywater from a school in rural India. J. Water Proc. Eng., 2020, 38, 101695.

4. Reshma, M., Kumar, M. and Rao, L., CFD multiphase simulation of oxygen transfer from diffused aeration system in synthetic wastewater. J. Water Process Eng., 2021, 40, 101920.

5. Priyanka, J., Raj, A. V., Connelly, S., Yeluripati, J., Richards, S., Rao, L. and Tamburini, M., Evaluating the performance of planted and unplanted HSSF-constructed wetlands: a case study from southern India. Ecol. Eng., 2021, 162, 106170.

6. Samia, R. et al., Sustainable water resources through harvesting rainwater and the effectiveness of a low-cost water treatment. J. Environ. Manage., 2021, 286, 112223.

7. Grimm, N. B. et al., Global change and the ecology of cities. Science, 2008, 319, 756-760.

8. Jain, M., Contemporary urbanization as unregulated growth in India: the story of census towns. Cities, 2018, 73, 117-127.

9. Carrondo, M. J. T., Lester, J. N., Perry, R. and Stoveland, S., Analysis of heavy metals in Sewage Sludge, Sewages and Final Effluent. Final report to the Department of the Environment for contracts, Government of the United Kingdom, 1978, DGR/ $480 / 66$.

10. Oghenerobor, B. A., Ohiobor, G. O. and Olaolu, T. B., Heavy metal pollutants in wastewater effluents: sources, effects and remediation. Adv. Biosci. Bioeng., 2014, 2(4), 37-43.

11. Tchounwou, P. B., Yedjou, C. G., Patlolla, A. K. and Sutton, D. J., Heavy metal toxicity and the environment. Mol. Clin. Environ. Toxicol., 2012, 3, 133-164.

12. Duffus, J. H., 'Heavy metals' - a meaningless term? Pure App. Chem., 2002, 74(5), 793-807.

13. Gupta, A., Rai, D. K., Pandey, R. S. and Sharma, B., Analysis of some heavy metals in the riverine water, sediments and fish from river Ganges at Allahabad. Environ. Monit. Assess., 2008, 157, $1-4$

14. GoI, The Environment (Protection) Rules, Ministry of Environment, Government of India, 1986

15. Shivashankara, G., Ranga, P., Ramalingaiah, K. and Rao, M. Characteristics of bulk precipitation in industrial area of Bangalore City. Indian J. Environ. Health, 1999, 41, 229-238.

16. Singh, A., Sharma, R. K., Agrawal, M. and Marshall, F. M. Health risk assessment of heavy metals via dietary intake of foodstuffs from the wastewater irrigated site of a dry tropical area of India. Food Chem. Toxicol., 2010, 48(2), 611-619.

17. Singh, K. P., Mohan, D., Sinha, S. and Dalwani, R., Impact assessment of treated/untreated wastewater toxicants discharged by sewage treatment plants on health, agricultural, and environmental quality in the wastewater disposal area. Chemosphere, 2004, 55(2), 227-255.

18. Lokeshwari, H. and Chandrappa, G. T., Impact of heavy metal contamination of Bellandur Lake on soil and cultivated vegetation. Curr. Sci., 2006, 91(5), 622-627.

19. Dheri, G. S., Brar, M. S. and Malhi, S. S., Heavy-metal concentration of sewage-contaminated water and its impact on underground water, soil and crop plants in alluvial soils of northwestern India. Commun. Soil Sci. Plant Anal., 2007, 38(9-10), 1353-1370.
20. Parashar, P. and Prasad, F. M., Study of heavy metal accumulation in sewage irrigated vegetables in different regions of Agra District, India. J. Soil Sci., 2013, 3, 1-8.

21. KC Valley project: IISc report warns of heavy metal content in treated water. Econ. Times, September 2018.

22. Varalakshmi, L. R. and Ganeshamurthy, A. N., Heavy metal contamination of water bodies, soils and vegetables in peri-urban areas: a case study in Bengaluru. J. Hortic. Sci., 2012, 7(1), 6267.

23. Callander, I. J. and Barford, J. P., Precipitation, chelation, and the availability of metals as nutrients in anaerobic digestion. II. Applications. Biotechnol. Bioeng., 1983, 25(8), 1959-1972.

24. Kiran, G., Kannan, P. and Das, G., Heavy metal removal by sulfate reduction using anaerobic sludge biomass from a wastewater treatment plant. In International Conference on Hydrology and Watershed Management, India, 2014

25. Roussel, J., Metal behaviour in anaerobic sludge digesters supplemented with trace nutrients. Ph.D. thesis, The University of Birmingham, UK, 2012.

26. Durga, M., Hoysall, C. and Ramachandra, T. V., Assessment of treatment capabilities of Varthur Lake, Bangalore, India. Int. J. Environ. Technol. Manage., 2011, 143, 84-102.

27. Bratkova, S., Angeloy, A., Nikolova, K., Loukanov A. and Plochey, S., Removal of $\mathrm{Cu}, \mathrm{Fe}, \mathrm{Ni}$ and $\mathrm{Zn}$ ions from waters with microbial produced hydrogen sulfide, Annu. Univ. Mining Geol. 'St. Ivan Rilski', 2011, 54, 175-180.

28. Aynsley, E. E. and Campbell, A. W., The laboratory preparation of hydrogen sulphide: a historical survey. J. Chem. Edu., 1958 , 35(7), 347-349.

29. Cioabla, A. E., Ionel, I., Dumitrel, G. A. and Popescu, F., Comparative study on factors affecting anaerobic digestion of agricultural vegetal residues. Biotechnol. Biofuels, 2012, 5, 39.

30. Morse, J. W. and Luther, G. W., Chemical influences on trace metal-sulfide interactions in anoxic sediments. Geochim. Cosmochim. Acta, 1920, 63, 3373-3378.

31. Haynes, W. M., Handbook of Chemistry and Physics, 95th edn, CRC Press, Boca Raton, Florida, USA, 2014.

32. Green, D. W. and Southard, M. Z., Perry's Chemical Engineers' Handbook, 9th edn, McGraw-Hill Education, New York, USA, 2019.

33. Olaniran, A., Balgobind, A. and Pillay, B., Bioavailability of heavy metals in soil: impact on microbial biodegradation of organic compounds and possible improvement strategies, Int. J. Mol. Sci., 2013, 14(5), 10197-10228.

34. Lewis, A. E., Review of metal sulphide precipitation. Hydrometallurgy, 2010, 104(2), 222-234.

35. Richardson, H. W., Handbook of Copper Compounds and Applications, 1st edn, CRC Press, Boca Raton, Florida, USA, 1997, pp. 273-275.

36. Anderson, G. K. and Yang, G., pH control in anaerobic treatment of industrial wastewater. J. Environ. Eng., 1992, 118(4), 551567.

37. Stinson, M. K., Control and treatment technology for the metal finishing industry: sulphide precipitation. Technical report prepared for United States Environmental Protection Agency, 1980, 625/8-80-003

38. Rice, E. W., Baird, R. B. and Eaton, A. D., Standard Methods for Examination of Water and Wastewater, 23rd edn, American Public Health Association, 2017, 3125-B.

Received 26 November 2019; revised accepted 20 April 2021

doi: $10.18520 / \mathrm{cs} / \mathrm{v} 121 / \mathrm{i} 1 / 109-114$ 